原著

食道静脈瘤に対する各種治療とその成績

\begin{tabular}{|c|c|c|c|c|c|c|c|}
\hline \multicolumn{8}{|c|}{ 山形大学第 1 外科 } \\
\hline 石山 & 秀一 & 片桐 & 茂 & 瀬尾 & 伸夫 & 飯澤 & 居 \\
\hline 布施 & 明 & 原 & 隆宏 & 亀山 & 仁一 & 塚本 & 亘 \\
\hline
\end{tabular}

\title{
CLINICAL STUDY ON THE TREATMENT OF ESOPHAGEAL VARICES
}

\author{
Shuichi ISHIYAMA, Shigeru KATAGIRI, Nobuo SEO, \\ Hajime IIZAWA, Akira FUSE, Takahiro HARA, \\ Jinichi KAMEYAMA and Masaru TSUKAMOTO
}

The 1st. Department of Surgery, Yamagata University, School of Medicine

\begin{abstract}
食道静脈瘤を有する門脈圧六進症64例に対する治療とその成績について検討した. 手術死亡は待期

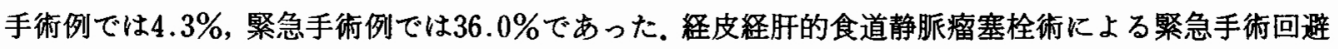
率は $85 \%$ で施行後待期手術までの期間は平均20日であった。術後再発例や手術不能例に対しては内視 鏡的硬化療法を行った，術後酸素消費量が低値を示するのに合併症が多く発生し，その程度も頭著で あった。遠隔死亡の原因は肝癌, 肝不全, 再出血であった。再出血率は $5.8 \%$ あっあた. 緊急止血には 経皮経肝的食道静脈瘤塞栓術が, 術後再発例, 手術不能例には内視鏡的硬化療法が有用で, 術後管理 には酸素消費量を指標にした呼吸循環管理が重要と考えられた。
\end{abstract}

索引用語 : 食道静脈痕, 経皮経肝的食道静脈瘤塞栓術, 内視鏡的硬化療法, 直達手術後呼吸循環動態, 直達手術後酸素消費量

はじめに

近年, 術前術後管理の進歩, 術成の改良により食道 静脈瘤に対する手術成績は向上してきたが,一方, 種々 の非観血的治療法が開発され普及してきている.また， 肝硬変症に対する内科的治療の進歩にともないこれら の患者の寿命がのび，高度肝障害を有する患者の治療 を行らことも多くなった。このよらな対象症例の状態 の変化や各種治療法の進歩にとあなってこれまでの治 療法を再評価し病期, 病態に応じた治療法を行らこと が必要と思われる。しかしながら，現在のところ，各 施設における各種治療の方法および評価は必ずしも一 致しておらず統一した見解は得られていない.そこで 教室で経験した食道静脈瘤の治療成績を検討し，あわ せて現時点における治療方針を報告する。

対象および方法

昭和52年12月より昭和59年 8 月までに教室で経験し

$<1985$ 年 2 月13日受理 $>$ 別刷請求先：石山 秀一 テ990-23 山形市蔵王飯田西前 山形大学医学部第 1 外科
た食道静脈瘤を有する門脈圧六進症64例で，原疾患の らちわけは肝硬変症53例, 特発珄門脈王穴進症 10 例, 肝外門脈閉塞症 1 例である。年齢, 性比は表に示すご とくである(表 1)．これらの症例を対象にして食道静 脈瘤に対する各種治療法とその成績について検討し た。

非観血的治療の方法の概要は以下のようである.

(1) 経皮経肝的食道静脈瘤塞栓術（PTO： percutaneous transhepatic obliteration of the gastric coronary vein)

表 1 症例の概要

\begin{tabular}{|c|c|c|c|}
\hline \multicolumn{4}{|c|}{ ( $552.12 \sim \mathrm{S59.8)}$} \\
\hline 原 & 应跑数 & 平均年命 & 男女比 \\
\hline 肝 现 症 & $53(46)^{2}$ & $53 \pm 10$ & $36: 17$ \\
\hline 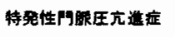 & $10(10)$ & $55_{ \pm 11}$ & $1: 9$ \\
\hline \multirow[t]{2}{*}{ 肝外问眼閶害痱 } & $1(1)$ & 52 & $0: 1$ \\
\hline & $64(57)$ & $53 \pm 12$ & $37: 27$ \\
\hline
\end{tabular}


PTOは Lunderquist らの方法"k準じて行った，塞 栓静脈は胃冠状静脈のみであるが，その根部を塞栓す るようにした。塞栓物質は主として isobutyl 2cyanoacrylate (Bucrylate ${ }^{\circledR}$ ) を用いたが，同部の流 速および内径の太さにより適宣, steel coil を併用し た.

(2) 内視鏡的硬化療法 (EIS : endoscopic injection sclerotherapy)

EIS は, 高瀬らの方法 ${ }^{2}$ に準じて ethanolamine oleateを用いて行った. Red color sign (RC) の陰性 化，および静脈瘤の F1への改善あるいは完全消失を目 標に日をあらためてくり返し行った。な技，食道静脈 瘤の内視鏡所見の記載は門脈王六進症研究会の食道静 脈瘤内視鏡記載基準によった。

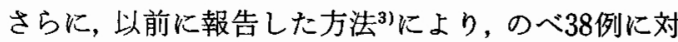
して Swan-Ganz catheter（SGC）を用いた monitoring を行って得た成績を解析した. 今回は特に酸素消 費量 $\left(\mathrm{VO}_{2}\right)$ と術後合併症との関係について, 術後経過 を通じての $\mathrm{VO}_{2}$ の最低値が $100 \mathrm{ml} / \mathrm{min} / \mathrm{m}^{2}$ 以下の群 （A 群：20例）と以上の群 (B 群：18例) にわけて検討 をくわえた。

\section{成 績}

\section{1. 手術成績}

64例中57例に手術を行った。手術々式のらちわけは, 開胸, 開腹による食道離断術 (ET： esophageal transection)扔よび胃上部血行遮断(DV： devascularization)・摘脾術 (SP： splenectomy) が29例（うち 9 例 は I 期的), 経胸的 ET 後経横隔膜的に DV・SP たもの 4 例（うち 3 例は fundic patch 法を用いた $\left.\mathrm{ET}^{4)}\right)$ で，ET, DV・SPをすべて行ったものは計33例 である.また，ET のみが 6 例，SP・DV のみが14例で， 他の 4 例は胃癌や胃悪性リンパ埋などを合併していた ため, 胃全摘術や胃切除術およびSPを行った。これら 57例のうち11例は緊急手術である。待期手術の死亡率 は $4.3 \%$ ，緊急手術では36\%であった（表 2 ）。手術死

表 2 手術々式の内訳と死亡数

\begin{tabular}{|c|c|c|}
\hline 乎粗々式 & 特期乎行 & 紫急乎行 \\
\hline 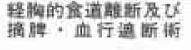 & $28(1)$ & $5(1)$ \\
\hline 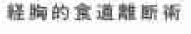 & $3(1)$ & $3(2)$ \\
\hline 摘髀 - 血行廘断術 & $13(0)$ & $1(1)$ \\
\hline \multirow[t]{2}{*}{ その他(男切除など) } & $2(0)$ & $2(0)$ \\
\hline & $46(2)$ & $11(4)$ \\
\hline
\end{tabular}

亡 6 例のらち 4 例が緊急手術， 2 例が待期手術で術前 状態は Child 分類 A が 1 例， B が 3 例，C が 2 例で あった。 また，死因は縫合不全に起因する多臟器不全 (MOF : multiple organ failure) $か 3$ 例, 後出血 1 例，腎不全 1 例で，他の 1 例は術前より誤膟性肺炎を 併発していたすのであった（表 3 ）。

\section{PTOの成績}

PTO を施行した症例は22例で，らち17例は出血例， 他の 5 例は出血はないが, 静脈瘤が内視鏡的に $\mathrm{CB}, \mathrm{F}_{2}$ 以上で RC 陽性のものである. 毉急止血目的で行った 17例中13例で塞栓に成功した，予防的に行った 5 例で は全例塞栓に成功した。塞栓不能であった 4 例中 3 例 は初期のすので手技の未熟さによるすのであるが，他 の 1 例は肝外門脈閉塞症例（経回腸静脈的門脈造影で 確認)で手技の成り立ち上, 塞栓の不可能なものであっ た. 合併症は22例中 3 例にみられたが（做小塞栓 1 例, 末梢門脈塞栓 1 例, 胸水貯留 1 例), 全例保存的に 改善し，臨床的に問題となることはなかった（表 4）。

PTOによる塞栓に成功した18例中13例には後日待 期手術を行ったが,手術をでの期間は平均 $20 \pm 12$ 日(緊 急止血例のみでは $24 \pm 10$ 日）と十分な術前検查および 状態の改善を行い得る期間であった. 特に緊急止血を 目的として行い, 塞栓に成功した13例は PTO 施行直 後に SB-tube を拔管することができ，その後急速に状 態が改善した。しかし， 2 例は塞栓後 4 日目，および 8 日目に再出血したため緊急手術を余儀なくされ，前 者は DICによる出血傾向で失ったが, 後者は 1 週間の 間に状態の改善がみられ，術後はまったく問題なく経 過した。なお，これら 2 例の塞栓部位は胃冠状静脈の 根部ではなく，第一分枝部であった，残りの 3 例のう

表 3 手術死亡例の概要

\begin{tabular}{|c|c|c|c|c|c|}
\hline 泟 & 解 & Child分桠 & 手断々式 & 死 & 栖役経週 \\
\hline $46^{7}$ & 5 & c & ET & MOF & $10^{8}$ \\
\hline 68 & 同 & c & ET & MOF & 12 \\
\hline 49 & 女 & B & ET.SP.DV & 鄞不全 & 10 \\
\hline 56 & 男 & B & SP. DV & 眠合侀湴 & 11 \\
\hline 51 & 男 & B & ET & 被出血 & 15 \\
\hline$\times 68$ & 女 & A & ET.SP.DV & MOF & 13 \\
\hline
\end{tabular}

表 4 PTO の成績

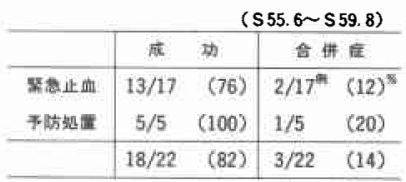


ち肝機能が不良であった 2 例に対してはEISを行っ たが，他の 1 例はその後の検査でび漫型の肝癌が認め られ，再出血はなかったが，急速に肝不全に移行して 約 1 力月後に死亡した（表 5 ).

入院時出血があり, PTOによる塞栓が不能であった 4 例は, PTO 導入前の出血例 5 例と同様に SB-tube による圧迫止血を行い，一時的に止血したが，全例， 24〜48時間経過して圧迫を解除した後，24時間以内に 出血したため緊急手術を行った。

\section{EIS の成績}

EIS の施行理由は食道離断術後再発 2 例, 高度肝障 害 2 例, 肝癌合併 1 例，高度腎障害 1 例，手術拒否 1 例, 緊急止血を目的に行ったもの1例であった(表 6 ). これら 8 例全例で $\mathrm{RC}$ の陰性化拉よび静脈瘤の改善な いし消失がみられたが，合併症として食道潰瘍が 2 例 に発生した。潰瘍は保存的に治瘉したが，亏ち1例は その後, 食道狭窄をきたし現在治療中である. EIS 後に 食道静脈瘤から出血した例は現在のところない。

\section{4. 術後呼吸循環動態の検討}

$\mathrm{VO}_{2}$ と術後合併症の発生率との関保をみると, 術後 に GOT が200 IU 以上の值を示したものはA 群では 35\%にみられたのに対して，B 群ではまったくみられ ずまた総ビリルビン值 (T-Bil)が $5 \mathrm{mg} / \mathrm{dl}$ 以上を示

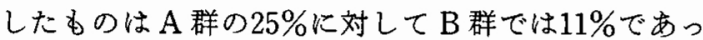
た。ささらに縫合不全は A 群で29\%，B 群で $7 \%$ にみら れ，手術死亡は $\mathrm{A}$ 群で10\%にみられたが，B 群では皆 無であった。このように術後合併症は B 群に比べ，A 群に多い傾向があった（表７）。

\section{表 5 PTO 施行後の治療}

\begin{tabular}{|c|c|c|}
\hline & 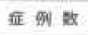 & 手街までの期间 \\
\hline 侍期乎衙 & $13^{|+|}$ & $20 \pm 12$ 日 \\
\hline 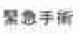 & 2 & 4 日. 8 日 \\
\hline 硬北湮徒 & 2 & $(-)$ \\
\hline 魚她 薑 & 1 & $(-)$ \\
\hline
\end{tabular}

表 6 内視鏡的硬化療法施行例の概要

\begin{tabular}{|c|c|c|c|}
\hline 粈 & 列 & 旅行理由 & 先行手術·処貫 \\
\hline $54^{*}$ & 男 & 術嵝再発 & ET.SP.DV \\
\hline 41 & 男 & $"$ & ET.SP.DV \\
\hline 50 & 女 & 高度肝滕 & Рто \\
\hline 70 & 男 & $"$ & Рто \\
\hline 49 . & 男 & 肝慧合件 & SP. DV \\
\hline 70 & 女 & 盈 & SP. DV \\
\hline 67 & 男 & 手輀拒否 & SP. DV \\
\hline 56 & 男 & 腎止血 & SP. DV \\
\hline
\end{tabular}

表 $7 \quad \mathrm{VO}_{2}$ と術後合併症

\begin{tabular}{|c|c|c|}
\hline & \multicolumn{2}{|c|}{$\begin{array}{c}\overline{V O} \\
{\left[\mathrm{ml} / \mathrm{min} / \mathrm{m}^{\prime}\right\rangle}\end{array}$} \\
\hline & 100BA & loost \\
\hline GOT $>200$ IU & $7 / 20$ (35) & $0 / 18(0)^{5}$ \\
\hline $\mathrm{T}-\mathrm{Bil}>5.0 \mathrm{mg} / \mathrm{dl}$ & $5 / 20$ (25) & $2 / 18$ (11) \\
\hline 合不全 & $4 / 14\langle 29\rangle$ & $1 / 14(7)$ \\
\hline 手茈 死亡 & $2 / 20(10)$ & $0 / 18(0)$ \\
\hline
\end{tabular}

ن $\mathrm{VO}_{2}$ と術後最高値を示した時の GOT およびT-Bil

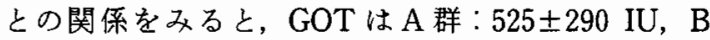
群 : $96 \pm 8 \mathrm{IU}$, T-Bil は A 群 : $5.3 \pm 1.7 \mathrm{mg} / \mathrm{dl}, \mathrm{B}$ 群 : $3.6 \pm 0.8 \mathrm{mg} / \mathrm{dl}$ で両者とも B 群に比べ $\mathrm{A}$ 群で高い傾 向がみられた（表 8 )。

$\mathrm{A}$ 群の $\mathrm{VO}_{2}$ の平均値は $79 \pm 3 \mathrm{ml} / \mathrm{min} / \mathrm{m}^{2}, \mathrm{~B}$ 群では $116 \pm 4 \mathrm{ml} / \mathrm{min} / \mathrm{m}^{2}$ であったが, $\dot{\mathrm{V} O} \mathrm{O}_{2}$ のこの違いを形成 する因子について検討すると，分時酸素運搬量 $\left(\mathrm{O}_{2}\right.$ Delivery) に有意差が認められた（A 群： $588 \pm 35 \mathrm{ml}$ / $\mathrm{min} / \mathrm{m}^{2}, \mathrm{~B}$ 群 : $\left.687 \pm 39 \mathrm{ml} / \mathrm{min} / \mathrm{m}^{2}\right)$. 一方, 動脈血酸 素含量 $\left(\mathrm{CaO}_{2}\right)$ は両群間㑝差はみられなかった。しか し, 心指数 (CI) は両群とも正常より高値を示すが $\mathrm{A}$ 群で $\mathrm{B}$ 群よりも有意に低く， $\mathrm{O}_{2}$ Deliveryに打ける両 群間の差は心指数の羑に起因するものであった。 また， 動静脈酸素較差 $\left(\mathrm{A} \cdot \mathrm{VDO}_{2}\right)$ は $\mathrm{A}$ 群で $\mathrm{B}$ 群より低い傾 向はあるものの, 有意差は認められなかった（表 9 ）.

\section{5. 遠隔成績}

食道静脈瘤に対する術後 3 年を経過したもの17例，

表 $8 \quad \dot{V O}_{2}$ と術後肝機能

\begin{tabular}{|c|c|c|}
\hline & \multicolumn{2}{|c|}{$\begin{array}{c}\mathrm{vo} \\
\left(\mathrm{m} / / \mathrm{min} / \mathrm{m}^{\mathrm{i}}\right)\end{array}$} \\
\hline & $\begin{array}{l}100 \mathrm{M} F \\
(n=20)\end{array}$ & $\begin{array}{l}100 \mathrm{ch}, \mathrm{L} \\
(\mathrm{n}=18)\end{array}$ \\
\hline GOT (HU) & $525 \pm 290$ & $96 \pm 1$ \\
\hline T-Bil (mg/dl) & $5.3 \pm 1.7$ & $3.6 \div 0=$ \\
\hline
\end{tabular}

表 $9 \dot{\mathrm{V}} \mathrm{O}_{2}$ と呼吸循環動態

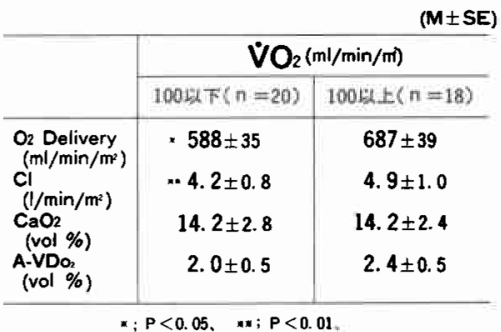


図 1 食道静脈瘤術後累積生存率

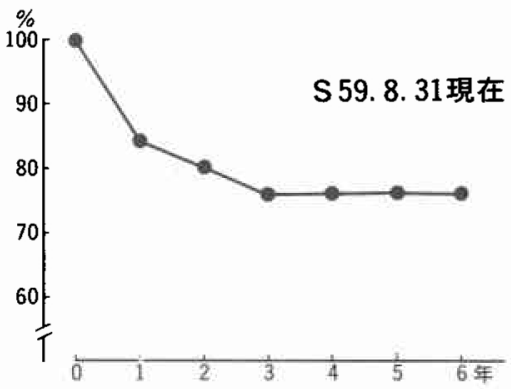

表10 遠隔死亡例の概要

\begin{tabular}{|c|c|c|c|c|c|}
\hline 症 & 的 & 手街々式 & 街後释遇 & 死 & 因 \\
\hline $63^{7}$ & 女 & ET.SP.OV & 3月 & 䀒不 & 金 \\
\hline 49. & 易 & ET & 3.5月 & 肝不 & 全 \\
\hline 58 . & 女 & ET.SP.DV & 4月 & 肝不 & 全 \\
\hline 52 . & 男 & ET.SP.OV & 8月 & 䀒 & 罳 \\
\hline 49. & 男 & SP. DV & 9月 & 旰 & 䨝 \\
\hline 31. & 女 & ET.SP.DV & 9月 & 再出 & 血 \\
\hline 67 . & 男 & SP. DV & 1 年10月 & 既 & 露 \\
\hline 52 . & 男 & ET & 2年 7月 & 旰 & 骨 \\
\hline
\end{tabular}

5 年を経過したもの 4 例と例数は少ないが, 累積生存 率は 3 年以後 $75.8 \%$ であった(図 1)，3 年以上生存 17 例の現在の生活状況を調查すると，1例が肝性脳症， 1 例が胆石症で他病院に入院しているほか，7例が復 職 8 例が特に障害のない日常生活をしていた。

遠隔死亡の原因は肝癌が 4 例, 肝不全が 3 例, 再出 血が 1 例であった（表10）.

耐術51例中再出血したものは 3 例で再出血率 $5.8 \%$ であった。うち1例は発見時すでにショック状態で他 病院死した。他の 2 例に対してはEISを行い，現在な 拈生存中である。

食道静脈瘤の外科的治療の対象はその出血に対する 治療が中心であり，基礎にある肝障害の程度およびそ の予後が治療法の選択を左右する因子となる. 本邦に おいてて，食道離断術を中心とする手術療法がきわめ て有効な治療効果をおさめてきたが，高度肝障害例や 緊急手術例に招いては術後に合併症を起こしやすく， 必ずしも満足すべき結果は得られていない。このよう な背景の下で, 近年, 種々の非観血的治療法が開発あ るいは改良され普及してきたが，実地臨床上，多彩な 治療法の選択や治療方針の決定には困惑を覚えるのが 実情である。特に，手術適応および術式の選択，出血 時の対応，手術不能例に対する治療，括よび術後管理 については論議の多いところである。
教室の食道静脈に対する手術々式は東大II 外科法5) に準じてET, SP・DVを行ってきた，その成績は全国 集計による成績6)と大差はない. 開院当初には, 肝機能 良好で他臓器合併症のない症例 9 例には I 期的にこれ らを行ったが術後縫合不全や離断部狭窄を来しやす かったため昭和56年 6 月からは全てII 期的に（原則と してETを先に) 行っている.また, 経胸的・経横隔 膜的にこれらを行い，かつ離断効果の完全化および術 後の逆流性食道炎防止などを考え fundic patch 法を 応用した術式)を施行した例もあるが, patch 部の壊死 による膿胸を 1 例経験してからこの術式を行わないよ らになった。

待期手術の死亡率は $4.3 \%$, 緊急手術の死亡率は $36.0 \%$ 緊急手術の成績は不良であった。手術死亡例 は6 例で，5ち 4 例が緊急手術例であった。これらの 4 例のらち 2 例は Child 分類 C, 他の 2 例は B であ ク，Aのものはいなかった，死因としては縫合不全に 起因する MOF が最も多かったが，出血時には生体の homeostasis が崩れていることが多く，肝をはじめと する主要藏器の機能障害が起こりやすい.したがって, 緊急手術に括いては手技的要因のほかに患者の栄養状 態や創傷の修復能などを含めた主要蔵器の機能が大き な因子となっているすのと考えられる。このように緊 急手術の成績は待期手術に比べ不良であり，緊急手術 は可及的に避けねばならない。

緊急止血の手段としては, 1950年, Sengs taken ら7) が報告して以来，いわゆる SB-tube がもっぱら使用さ れ，ある程度の効果をあげてきた。しかしながら，SBtubeによる止血はballoonによって压迫している間 はほとんぞの例で止血が期待できるが，正迫を解除し た後に再出血することが多く止血率は56.1\% ${ }^{6)}$ といわ れ必ずしも満足できる効果ではないささらに SB-tube により長時間圧迫された食道壁は手術時, 脆弱になっ ていることが多く縫合不全をきたす一因となるものと 考兄られる。

そこで教室では緊急止血の手段として昭和 55 年 6 月 より SB-tube による圧迫止血後ただちにPTOを行っ

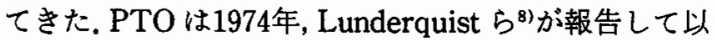
来，本邦でも行われるようになり，普及してきた9)10). 導入初期の 3 例および肝外門脈閉塞症では塞栓不能で あったが，特に緊急止血を目的として行い，塞栓に成 功した13例では SB-tube を早期に抜管でき，急速な状 態改善を期待できた。13例中11例（85\%）で緊急手術 を避けることができ， SB-tube 挿入中に起こることが 
多い誤絔性肺炎などの合併症はまったくみられなかっ た。他の 2 例は PTO 後再出血したため, 緊急手術を余 儀なくされ1例を失った. しかし，残りの1例はPTO 施行術 1 週間を検查と状態改善のために有効に使らこ とができ，さらにSB-tubeによる長期王迫のための食 道壁の脆弱化もみられず, 手術後まったく問題なく経 過した. また, PTOの合併症で臨床上問題となるもの はなかった。

このように PTOはその手技に習熟すれば肝外門脈 閉塞症などの手技の成り立ち上塞栓が不能な例を除い て緊急止血には安全かつ有効な手技とい党る．Lunderquist らの原法”によれば，食道静脈瘤に向からす べての静脈を塞栓するとあるが，われわれは最も太い 側副血行路, すなわち胃冠状静脈のみを，その根部で 塞栓するようにしてきた。塞栓成功例中再出血した 2 例では, 両者ともその根部で塞栓されていなかったこ とを考慮すると，緊急止血のためには胃冠状静脈の塞 栓だけで十分であるが，その根部で塞栓することが肝 要であろう.

SB-tube 就よびPTOにより緊急手術を回避しえた 症例で肝機能良好なるのに対しては待期手術を行った が, 前述のごとく, PTO 施行直後より止血効果がみら れただちに術前準備を行うことができるため，PTO 施行後約 3 週間で手術に必要な検查および状態の改善 を十分行うことができる。

しかし, 肝機能障害あるいは他臟器障害が著しく手 術を行えない症例もあった。特に最近の肝硬変症に対 する内科的治療の進歩により, 高度肝障害および肝癌 を有する例が多くなる傾向にある，このような症例に は EIS が適応と考学られる. EIS は1939年, Crafoord

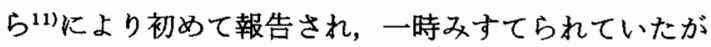
最近の内視鏡の進歩，塞栓物質の改良などによりみな おされ普及してきた ${ }^{12113)}$. 教室でも昭和57年 6 月より 食道離断術後再発, 高度肝障害, 肝癌合併, 高度他臓

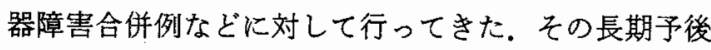
については未だ例数が少ないため評価できないが，現 在のところ, 施行後食道静脈癌から出血したものはい ない.

従来, EIS は緊急出血の目的で開発されたもので緊 急止血率は70\% ${ }^{6)}$ (高瀬らは95\%) ${ }^{13)}$ といわれる。 しか しながら，杉浦ら ${ }^{14)}$ が指摘しているよらに EIS 後は食 道壁の炎症が強く，後には洀痕組織に扣きかわる，わ れわれの症例でも 2 例に施行後早期潰瘍を形成し， うち1例は後に疲痕狭窄をきたした。したがって EIS
後早期に手術を行うと離断部の縫合不全, 穿孔などが 起こりやすいと考学られ，EIS 後の手術時期の決定に は慎重を要すると考党られる。一方, 術後再発例では $\mathrm{DV}$ SP により脾静脈は細くなり, 新生された静脈瘤 に向から側副血行路も細い網目状を呈することが多い ため, PTOによる塞栓は困難である. したがって, こ のような術後再発例に対してはEISがよい適応と考 兄られる。を, 手術不能例に対してはPTO 単独では 再発する可能性が大きく ${ }^{10)}$, 繰り返し行うには手技が 繁雑であることなどより EISあるいはEIS と PTO の併用がよいと考えられる。

さて,以上のようにして緊急手術を避け症例の病期, 病態に応じた治療法を選択し, 手術可能例には手術を 行うのであるが, 成績向上のためには術後管理が重要 であることはいらまでもない，肝硬变症例では，肝の みならず他の主要臟器および代謝系の障害を合併して いることが多い。われわれは各種病態下において SGC を用いた monitoringを行い, あらゆる䁍器の代謝に 不可欠である酸素の運搬能を重視して術後管理を行っ てきて招り，その重要性を報告してきだ3.

門脈圧六進症では, いわゆる hyperdynamic state を示す例が多いが，それにもかかわらず酸素摂取の障 害がみられることは既報》のとおりである，今回，この 末梢での酸素摄取の程度を表す指標である $\mathrm{VO}_{2}$ の值 により 2 群に分けて術後合併症との関係をみたとこ ろ, $\mathrm{VO}_{2}$ が低値を示す群で合併症を発生しやすく， ま た, 術後肝障害の程度も著明となる傾向がみられた。 $\mathrm{CI}$ が正常に比べ高值を示すにもかかわらす゚ $\mathrm{VO}_{2}$ が低 いのは A- $\mathrm{VDO}_{2}$ の狭少化がみられるためで，その原因

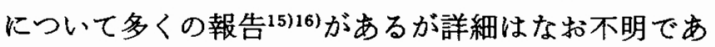
る. 原因はともあれ, AV-DO 2 は両群ともに, 著しい狭 少化を示し, 両群に有意差はなかった。すなわち, 両 群間の $\mathrm{VO}_{2}$ の差は $\mathrm{A}-\mathrm{VOD}_{2}, つ ま り$, 末梢での酸素摄 取の障害の差によるものではなく分時酸素運搬量 $\left(\mathrm{O}_{2}\right.$ Delivery）の違いによるものであった。 またこれは $\mathrm{CaO}_{2}$ に差がないことから， $\mathrm{CI}$ の差に起因するもので あった。換言すれば，さらに hyperdynamicにすれば 的 ${ }_{2}$ の低下を免れることができる可能性があるという ことである. したがって, 門脈圧え進症の術後管理に あたっては hyperdynamic stateを維持すること,つ まり, 賏血や低酸素血症を是正し, 循環血液量を保ち ながら強心剤を用いて十分なCI 確保するだけでな く、 $\dot{\mathrm{V}} \mathrm{O}_{2}$ 監視しながら適切な呼吸循環管理を行うべ きであろらと考学る。 
図 2 食道静脈瘤の治療方針

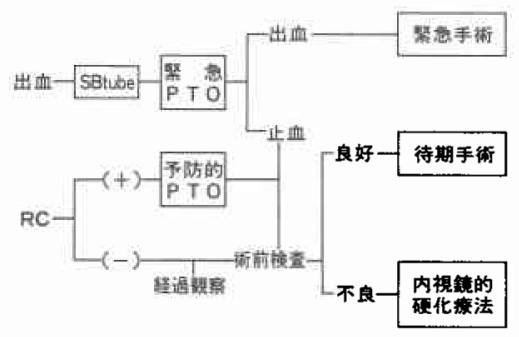

直達手術耐術例の予後は 5 年生存率60 75\% ${ }^{6}$ とい われる。教室の 5 年生存率は $75.8 \%$ である。近年の内 科的管理の進歩により，その成績はさらに改善される ことが期待できるものと考えられる. また，術後 3 年 以上経過した症例の生活状況において，ほとんどの症 例が復職あるいは特に障害のない日常生活を送ってい ることから, quality of lifeを重視する観点からみて も, 手術の遠踹成績は注满足できる結果と考えられ る.

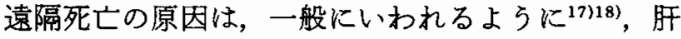
癌, 肝不全, 出血であった。これらの中で特に肝癌は, 志方 ${ }^{199}$ の報告によれば通常みられる型の肝硬変症の 40.9\%に合併するものであり, さらに増加する傾向に ある.今後は肝硬変症に対する集学的治療の一環とし て, いわゆる肝癌の高危険群の長期管理による肝癌の 早期発見, 早期治療が重要と考えられる.

以上, 食道静脈瘤に対する教室の治療とその成績に ついて述べたが，このような成績をもとに現在のとこ ろ，われわれは図 2 に示すような治療方針をとってい る. 最近の傾向としては非観血的治療を駆使して手術 適底範囲を縮小しようといら試みが913)が多くみられ るようになってきた，原疾患を根治できない疾患の性 質上順当な考え方と思われるが，それぞれの治療法に ついての症例が増やして検討したいと考えている.

\section{結語}

教室の食道静脈瘤に対する治療とその成績について 報告した。

1.手術の成績は緊急手術を除いてほぼ満足できる ものであった。

2. 緊急止血にはPTO が有効であった。

3. 術後再発例, 手術不能例には EIS が有効であっ た.

4. 術後管理にはSGCを用いた monitoringを行 い， $\mathrm{VO}_{2}$ を指標にして適切な呼吸循環管理を行う必要 があると考えられた。
以上の成績に基づき，現在われわれが考えている食 道静脈瘤に対する治療方針についても言及した。 本論文の要旨は第 46 回日本臨床外科医学会総会（昭和59 年11月, 東京), ラウンドテーブル・ディスカッションにお いて発表した.

\section{文献}

1) Lunderquist A, Borjesson B, Owman $T$ et al : Isobutyl 2-cyanoacrylate (Bucrylate) in obliteration of gastric coronary vein and esophageal varices. Am J Roentgenol 130:1-6, 1977

2）高瀬靖広, 折居和雄, 豊 健住：食道静脈瘤に 対する内視鏡的栓塞療法の治療成績. 日消外会誌 $14: 445-450,1981$

3）石山秀一, 中村尚志, 松本 繁汪か：門脈王六進症 の血行動態と術前術後管理. 外科と代謝 - 栄養 16:101-109, 1982

4）粸福哲彦, 渡辺正敏, 石田 薰はか：合併症の少な い食道離断術. 手術 $35: 1173-1180 ， 1981$

5）杉浦光雄, 市原荘六, 野村 満注か：門脈王亢進症 の外科治療一とくに東大第 2 外科法について。 日 医新報 $2410: 7-11,1970$

6）小林廸夫：食道静脈瘤に対する外科治療の現況と 問題点. 手術 $37: 1277-1285,1983$

7) Sengstaken RW, Blakemore $\mathrm{AH}$ : Balloon tamponade for control of hemorrhage from esophageal varices. Ann Surg $131: 781-789$, 1950

8) Lunderquist A, Vang J: Transhepatic catheterization and obliteration of coronary vein in patients with portal hypertension and esophageal varices. N Engl J Med 291 : 646-649, 1974

9）打田日出夫, 吉岡哲也, 大石 元ほか：食道静脈 瘤。外科治療 $49: 285-297,1983$

10）石川羊男，伊藤信義：PTPを利用した食道静脈瘤 破裂の予防措置. 小戸廸郎, 瀧野辰郎編, 肝硬変と 肝腫瘍. 東京, 医学書院, 1984, p84-93

11) Crafoord C, Frenckner P: New surgical treatment of varicous veins of esophagus. Acta Otolaryngol $27: 422-429,1939$

12）渡辺五朗, 海北信孝, 川崎誠二ほか：食道静脈瘤に 対寸る内視鏡的硬化療法. 手術 $37: 723-728$, 1983

13）高瀬靖広：食道静脈瘤の内視鏡的硬化療法。水戸 廸郎, 瀧野辰郎編, 肝硬変と肝腫瘍. 東京. 医学書 院, 1984, p94-100

14）杉浦光雄, 八木義弘,二川俊二ほか：食道静脈瘤の 手術適応と限界. 消外 7:539-546, 1984

15) Nespoli A, Bevilacqua G, Staudacher $C$ et al : Pathogenesis of hepatic encephalopathy and hyperdynamic syndrome in cirrhosis. Arch Surg 
$116: 1129-1138,1981$

16）山名秀明, 掛川暉夫, 古賀信行ほか：門脈王六進症 に㧍ける hyperdynamic stateの成因に関する検 討. 日消外会誌 $16: 58-67,1983$

17）井口潔, 橋爪誠：食道静脈瘤の natural history. 消外 7:525-528, 1984

18）二川俊二, 杉浦光雄, 島 文夫ほか：食道静脈瘤に
対する直達手術の比較検討. 日消外会誌 11 ： $616-620,1978$

19) Sikata $T$ : Primary liver carcinoma and liver cirrhosis. In Okuda $\mathrm{K}$ and Peters RL (ed) : Hepatocellular carcinoma. Wiley Medical, New York, 1976, pl69-23 